\title{
Understory vegetation in planted pine forests governs bird community composition and diversity in the eastern Mediterranean region
}

\author{
Uzi Dagan and Ido Izhaki (D)
}

\begin{abstract}
Background: Managed forests can become a seminatural habitat by allowing natural vegetation to establish under the tree canopy. The aim of this study was to examine how this natural understory vegetation in pine plantations affects bird community composition and diversity. We compared bird communities in three types of pine forest plantations that differed in the composition of their understory vegetation.

Results: One thousand four hundred seventy-six birds of 33 species were observed in the three different forest habitats over two years. We found that the presence and composition of understory vegetation had a major role in determining bird community composition, richness, complexity and diversity.
\end{abstract}

Conclusions: To ensure pine forest with high biodiversity in the eastern Mediterranean region, the understory needs to be rich in shrubs that are attractive to birds and other natural fauna.

Keywords: Pine forest, Plantation, Understory, Vegetation, Birds, Community composition, Diversity, Habitat structure

\section{Background}

\section{General}

Seven percent $(98,600 \mathrm{ha})$ of the state of Israel is covered by managed forests, whereas only $1.3 \%$ (18,500 ha) is natural woodlands (CBS - Statistical abstract of Israel 2014; JNF 2014). More than one third (35\%) of the managed forests were planted before 1970 and $36.1 \%$ $(40,700 \mathrm{ha})$ of them are stands of pines and mixed pine forests (JNF 2014). Managed coniferous forests differ markedly in their understory vegetation: whereas some forests may be bare of vegetation, other stands of the same age can be rich in shrubs and climbers (Ne'eman and Izhaki 1999; Dufour-Dror 2005; Fuller et al. 2007). This variability is an outcome of different forestry management and the wide variety of environmental characteristics among the managed pine stands, such as elevation, slope, bedrock, soil and fire history (Schiller et al. 1997; Ne'eman and Izhaki 1999).

\footnotetext{
* Correspondence: izhaki@research.haifa.ac.il Department of Evolutionary and Environmental Biology, University of Haifa, 3498838 Haifa, Israel
}

\section{ecosystem services}

There is no doubt that biodiversity conservation is essential to maintain ecosystem services, given the 
complex ecological interactions between biotic and abiotic components that eventually benefit humans (Mace et al. 2012). Thus, forest biodiversity is important to support human existence and well-being (Osem et al. 2014). Indeed, the first priority of forest management policy in Israel nowadays is to offer recreational and outdoor activity (Osem et al. 2014; Storch et al. 2018). However, forest ecosystems worldwide provide many additional services, including conservation, supply of wood, improving soil quality (Fox 2000) and air quality (through air filtration), rainwater drainage (Bolund and Hunhammar 1999), climate regulation, carbon storage and natural pest control (for example, by providing night shelter for insectivorous birds) (Nasi et al. 2002).

The current approach of nature conservation authorities is that conservation efforts should not be limited to nature reserves and, therefore, should also be directed toward managed, seminatural forest areas (Harris 1984; Wilcove 1989; Hansen et al. 1991). In light of the conservation and ecological importance to maintain high biodiversity in managed forests, priority should be given to enrich the forest structure. There is a strong correlation between diversity composition and forest structure (Urban and Smith 1989). Thus, complexity in forest structure promotes wild plant and animal diversity (Hansen et al. 1991).

\section{Birds as bioindicators}

A forest management policy that will encourage biodiversity should be based on research that clarifies whether different types of managed forests maintain different levels of biodiversity as well as how ecological attributes of different forest types affect biodiversity. Such knowledge will provide forest managers with recommendations on how to administer forests to support high biodiversity. However, it seems almost impossible to separate the effects of various management methodologies on biodiversity (Lindenmayer et al. 2000).

Many studies in various ecosystems have shown that birds can serve as bioindicators (Koskimies 1989; Daily et al. 1993; Canterbury et al. 2000; Mikusinski et al. 2001; Gregory et al. 2003; Gregory 2006; Padoa-Schioppa et al. 2006). It has also been documented that bird biodiversity can be enhanced by forest design and management (Fuller et al. 2007; Quine et al. 2007). In the Mediterranean region, forest birds are considered good bioindicators and also play important roles in ecosystem functioning (Gil-Tena et al. 2007). Furthermore, many bird species can be considered keystone species due to their important roles in ecosystems as predators, prey and pollinators (Daily et al. 1993). Bird density and diversity indicate the quality of the habitat for other organisms (Gregory et al. 2003), and thus bird-count data is relevant to land-management and conservation decisions (Bock and Jones 2004). Bird censuses are efficient and indicate bird abundance and reproductive success over large spatial scales (Carignan and Villard 2002; Padoa-Schioppa et al. 2006).

In Israel, 30-41 bird species were observed in pine forests, including $65 \%$ all-year residents, $14 \%$ winter residents, 9\% summer residents and 12\% migratory birds (Izhaki and Adar 1997; Sorek and Pervolotsky 2016). Only $28 \%$ of these species are forest obligators whereas the other species inhabit the maquis (scrubland vegetation of the Mediterranean region) as well (Sorek and Pervolotsky 2016). However, field experiments designed to assess the impact of forest management on bird abundance and biodiversity are rare in Israel. In light of the fact that $7 \%$ of the lands in Israel are managed forests, it is rather surprising that the study of bird communities in Israeli forests has largely been overlooked (especially in central and northern Israel) (but see Rankevich and Warburg 1983; Izhaki and Adar 1997; Shochat et al. 2001).

The relationship between bird diversity and the environmental attributes of managed coniferous forests was, and still is, the subject of many studies in Europe (Patterson et al. 1995; Paillet et al. 2010; Rosenvald et al. 2011; Czeszczewik et al. 2015). Forest structure is an important factor in birds' habitat choice (Sweeney et al. 2011). The composition of bird communities is governed by the stage of forest growth and the understory characteristics that affect the aural, visual and physical environments (Schieck 1997; Whelan and Maina 2005). There are several factors that may increase species richness of forest birds: plantation size (Robbins 1980; Izhaki 2000), forest age (Izhaki 2000; Moning and Müller 2009), plant species richness (Lynch and Whigham 1984; Izhaki 2000), successional stage, understory composition (Izhaki 2000) and canopy height (Robbins 1980). As forests become denser with taller growing shrubs, trees and climbers, they support higher bird densities (Patterson et al. 1995; Sweeney et al. 2011) and biodiversity (Fuller 2003).

The main goal of our study was to establish recommendations for pine forest management policy in Israel. To that end, we have addressed the following specific questions: (1) How does forest structure influence bird community composition, richness abundance and complexity? (2) What is the effect of understory vegetation on bird diversity? The results and recommendations of this study could be applied in semi-arid forests across the Mediterranean basin.

\section{Methods}

\section{Study plots}

The study was carried out in a non-industrial, managed coniferous forests in northern Israel, from the Carmel 
ridge in the west to Megido in the east. The climate of the area is typical for the Mediterranean with an annual rainfall of 600 to $700 \mathrm{~mm}$, mainly concentrated between December and February (Goldreich 1994). Our bird survey included 20 forest plots, that were at least $250 \mathrm{~m}$ apart (Fig. 1) to minimize the potential for individual birds to be counted at multiple points (Shriner 2001; Brown et al. 2015). All plots were more than 50 years old and larger than 5 ha (JNF forest database 2015).

These forests were dominated by two planted pine species: Aleppo pine (Pinus halepensis) and Brutia pine (Pinus brutia). Tree density ranged from 1500 trees per ha with a limited number or an absence of shrubs, to an open forest with less than 500 trees per ha with shrubby patches and gaps with mainly herbaceous vegetation (Ne'eman and Izhaki 1999). The understory beneath the managed pine trees varied greatly among the study plots and constituted a mosaic of small trees such as Quercus calliprinos and Pistacia palaestina, shrubs like Pistacia lentiscus, Phillyrea latifolia, Calicotome villosa, Rhamnus lycioides, and climbers such as Smilax aspera and Clematis cirrhosa (Schiller et al. 1997). Habitat structure in this study followed the definition of Smith et al. (2017) and included soil cover, tree density, tree height, tree volume, vegetation cover and more (for specific species and total coverage see Table 3 in Appendix).

We selected the study plots in the three main forest habitat types in our landscape (Fig. 1): (1) dense pine forest with a diverse understory of shrubs and shrub-like trees (DF, $n=8$ plots); (2) open pine forest with natural broadleaf trees and an understory of large shrubs (OF, $n=6$ plots); and (3) dense pine forest with (almost) no understory except herbaceous vegetation (NF, $n=6$ plots).

\section{Bird surveys}

Bird surveys were conducted at 20 fixed point counts (Bibby 2000), one point per study plot. The minimum distance between two points was $250 \mathrm{~m}$, which is much above the recommended minimum distance between point-count stations (Huff et al. 2000). Each point count was located at least $50 \mathrm{~m}$ deep in the forest to avoid edge effect. A circular point-count method with a 50-m radius (Reynolds et al. 1980; Shriner 2001; Brown et al. 2015)

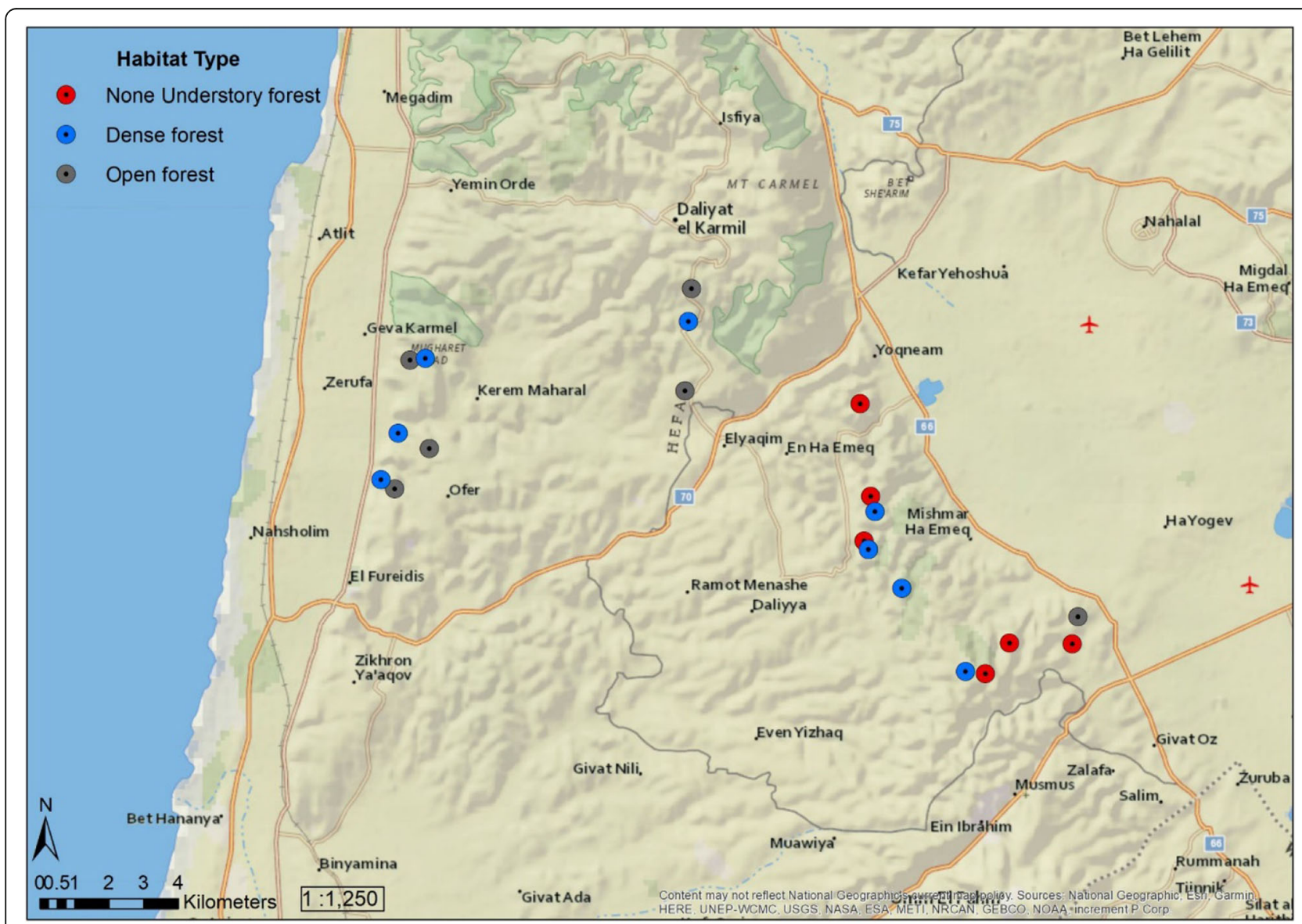

Fig. 1 The map of the study area and the location of the study plots of each of the three types of forest habitats 
was used to estimate bird density, species richness and diversity in each study plot (Sweeney et al. 2011; Brown et al. 2015). All birds heard or seen from the census station over a 10-min interval (Reynolds et al. 1980; Shriner 2001) were registered by species, date of detection and distance in 2 radius bands: 0 to $30 \mathrm{~m}$ and $30 \mathrm{~m}$ to infinity (plot edge) from the observer (Bibby 2000). Birds that were flushed from the plot when approaching the point count station were recorded as present in the counting time (Reynolds et al. 1980; Marsden 1998). Birds crossing in flight over the station (up to $25 \mathrm{~m}$ ) during the census were counted (Reynaud and Thioulouse 2000).

Each point count was visited monthly in the fall (mid-August to late October), winter (late October to March), spring (March to June) and summer (June to mid-August) over two years (2015-2017). Thus, we visited each point count 24 times during this study. Bird counts were carried out in fine weather between sunrise and none in the spring, summer and fall, and between 07:00 and 14:00 in the winter. Point-count data was used to determine bird abundance, density (Patterson et al. 1995; Bibby 2000; Alldredge et al. 2007), richness (Patterson et al. 1995), diversity and community composition (Alldredge et al. 2007) in the three types of forest habitat.

\section{Comparing habitat structure in the three types of forest habitat}

The parameters of habitat structure (mainly vegetation measurements) were carried out by two transects at a $25-\mathrm{m}$ radius around each point count and included the cover percentages of understory perennial species, herbaceous vegetation and exposed soil and rock surfaces (Schiller et al. 1997; Marsden 1998). Plant species were recorded every $10 \mathrm{~cm}$ along the transects and were categorized into life form, height level (Schiller et al. 1997) and species. The cover percentage of each species and life form was categorized into four layers: ground (below $1 \mathrm{~m}$ ), shrub level (1 to $5 \mathrm{~m}$ ), low canopy (5 m up to canopy level) and tree top level (Marsden 1998; Fuller 2003). The percentages were calculated independently for each life form, and therefore, the total cover percentage could reach more than 100\% (Schiller et al. 1997; Ellis and Betts 2011). The following parameters were measured for pine trees: average percentage canopy cover, tree top height, tree diameter at breast height and tree density (Schiller et al. 1997; Czeszczewik et al. 2015). The vegetation survey was carried-out in spring 2017 in all plots.

\section{Data analysis}

Discriminate analysis was used to determine if the three types of forest habitat were indeed different in vegetation structure using SPSS21 (SPSS 2015). Non-metric multidimensional scaling (NMDS) ordination was used to estimate the effect of vegetation characteristics (canopy cover percentage, understory cover percentage, trees per ha, etc.) on bird community composition in the three types of forest habitat. For this analysis we used $R$ package vegan (Oksanen et al. 2016) and the ade4 package (Dray and Dufour 2007), as well as the Monte Carlo method to test the significance of the results.

We used species network analysis to compare the complexity of the bird communities among the three forest types. To this end, we calculated three network parameters for each forest type for each season using the igraph $\mathrm{R}$ package (Csardi 2006): (a) normalized degree centrality which indicates the number of nearest neighbors of each bird species (nodes) divided by maximum possible degree, (b) weighted degree which indicates the sum of the frequency of interspecific associations and (c) closeness centrality which representing the distance between the species in the network.

Bird species diversity and accumulation in each type of forest habitat were estimated by Chaol a non-parametric index of predicted species richness, using in $\mathrm{R}$ package vegan. Bird abundance and density were calculated with $R$ package Distance in (Miller 2016), within $30 \mathrm{~m}$ of the point count station and more than $30 \mathrm{~m}$ to the plot edge, using model that consider and calculate the change in detectability with distance and calculate the density per square m (Buckland et al. 2008).

We used ANOVA through $\mathrm{R}$ package Stats ( $\mathrm{R}$ Core Team 2016) to compared the three different types of forest habitats for (a) parameters that were not included in the ordination - bird density, species richness and diversity per point count and (b) the three complexity indices in each season. ANOVAs were followed by Bonferroni multiple Comparison Tests. $p$ values of less than 0.05 were considered significant for all tests.

\section{Results}

The structural difference among the three types of forest habitats

Linear Discriminant Analysis significantly showed that the three types of forest habitat were distinctive mainly based on vegetation attributes (Fig. 2, Table 4 in Appendix). The coverage of Rhamnus lycioides and other shrubs were the two predominant vegetation factors which affected the $X$-axis of the discrimination, whereas tree density and the coverage of Smilax aspera and Pistacia lentiscus were the main factors that contributed to the discrimination on the $Y$-axis (Fig. 2, Table 4 in Appendix). Thus, the main shrubs in the dense forest (DF) were $S$. aspera and $P$. lentiscus whereas the main shrub species in the open forest (OF) was Rhamnus lycioides (Fig. 2). Rhamnus lycioides in the OF had the highest coverage of $61.9 \% \pm 2.15 \%$, $(n=6)$ representing both 


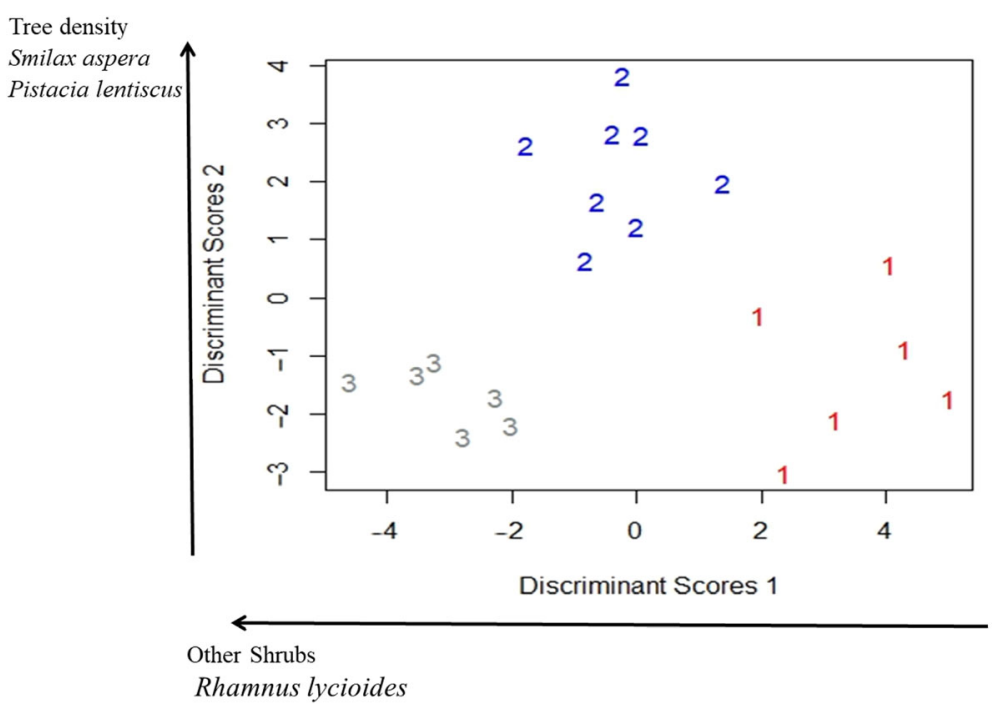

Fig. 2 Ordination of the discriminant analysis among the three types of forest habitats that mainly based on vegetation parameters (Wilks' lambda $=0.024$, chi-square $=46.622, \mathrm{df}=20, p=0.001)$. (1, in red) No understory forest $(n=6)$; $(2$, in blue) Dense forest $(n=8)$; and (3, in gray) Open forest $(n=6)$. Only the major discriminant factors in each axis are listed by the arrows. For full list of parameters that affected each discriminant axis see Table 4 in Appendix

horizontal and vertical vegetation coverage, but only $25.4 \% \pm 1.1 \%,(n=8)$ in the DF and $2.2 \% \pm 1.93 \%,(n=6)$ in the no understory (NF) plots. The tree density was the highest in the DF habitat $(1525 \pm 363$ per ha, $n=6)$, than in the NF habitat $(1100 \pm 412$ per ha, $n=8)$, and the low tree density was in the OF habitat $(367 \pm 137$ per ha, $n=6)$. Shrub coverage in the DF habitat was $119 \% \pm$ $28 \%(n=8)$ and $111 \% \pm 13 \%(n=6)$ in the OF habitat, whereas, in the NF habitat, only $0.7 \% \pm 0.81 \%(n=6)$ of shrub coverage was found (Table 3 in Appendix). For the full list of habitat characteristics that affected the discriminant analysis between the three forest types see Table 3 in Appendix.

\section{The impact of habitat structure on bird community composition}

During this study, a total of 1476 birds of 33 species were observed over 189 survey days between 2015 and 2017. The full list of birds that were observed in each forest type appears in Table 5 in Appendix. The NMDS ordination, which was based on all observations from all seasons, demonstrated that habitat structure, mainly the vegetation attributes was significantly associated (Monte Carlo test, $p=0.01$ ) with bird community composition (Fig. 3, Table 6 in Appendix). The bird communities in the two forest habitats with understory vegetation (DF and $\mathrm{OF}$ ) were overlapped to some extent, whereas both were markedly different from the NF habitat (Fig. 2). The NMDS ordination plot shows that the composition of bird community was primarily affected by total shrub coverage $(p=0.001)$, total vegetation cover $(p=0.024)$,
Rhamnus lycioides coverage $(p=0.028)$, Smilax aspera coverage coverage ( $p=0.043)$, (Fig. 3, Table 6 in Appendix).

Bird abundance, richness and diversity in the three types of forest habitat

The most common bird species observed in this study (across the three types of habitat) were the Sardinian warbler (Sylvia melanocephala) with 459 individuals, the Common chaffinch (Fringilla coelebs) with 173 individuals and the Blackbird (Turdus merula) with 130 individuals. The bird community networks differed across the three forest types (Fig. 4). Three resident species (S. melanocephala, Garrulus glandarius and Streptopelia decaocto) consistently presented across the three forest types (see also Table 5 in Appendix). Compared to their relatively high abundance in the DF and OF habitats, the European robin (Erithacus rubecula) was not spotted in the dense pine forest with no understory (NF). Two species (Great tit, Parus major, and Blackbird, Turdus merula) were also very rare in the (NF) habitat (Table 1). On the other hand, the abundance of Common chaffinch (Phylloscopus collybita) was higher in the NF habitat, but not significantly (Table 1).

The network complexity was far greater in the open and dense habitats (OF and DF, respectively) in comparison with the forest without understory (NF) in each season (Fig. 5). The species in the NF forest significantly associated with a proportionately lower number of other species (normalized degree) in fall and winter but not in spring (Fig. 5a) and a lower frequency of interspecific 


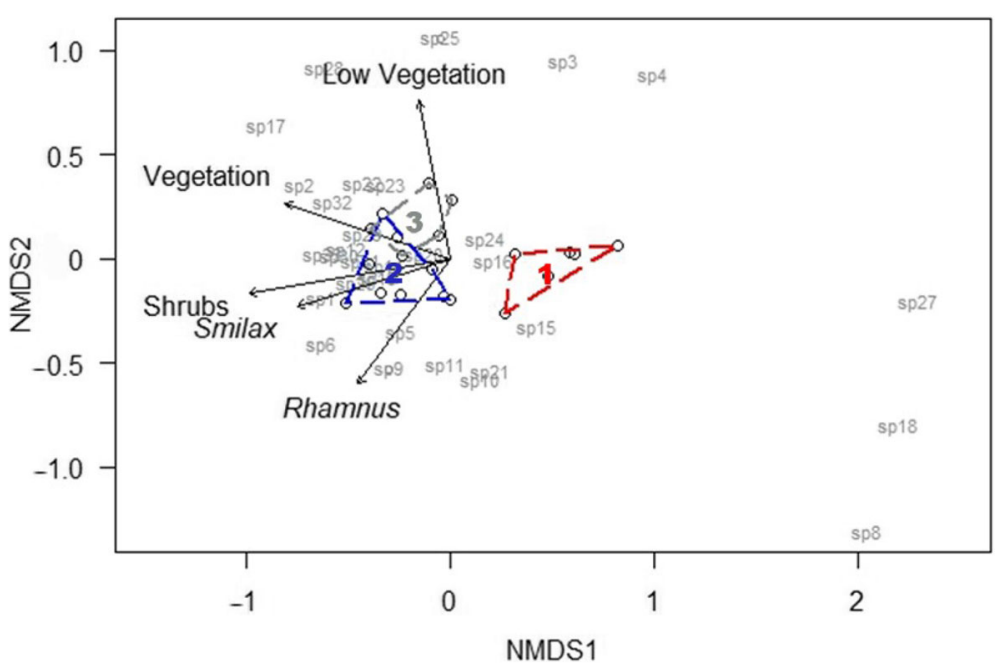

Fig. 3 NMDS ordination of the bird species in relation to the habitat structure parameters in three types of forest habitats: No understory forest, NF (1), Dense forest, DF (2) and Open forest, OF (3). Significant separation between the No understory forest habitat and the other two habitats are marked in polygons (NF in red, DF in blue, OF in gray). Bird species are marked in light grey numbers (for full bird names see Table 5 in Appendix); plots are marked by circles and arrows represent vectors of the significant factors that contributed to the ordination $(p<0.05)$ : See Table 6 in Appendix for more information on the statistical results of the MNDS ordination

associations (weighted degree) than did species in the other two forest habitats, however, it was significant only in fall (Fig. 5b). The distance among species (closeness) was significantly larger in the NF forest than the other two forest types in spring but with no significant differences in the other two seasons (Fig. 5c).

Total bird density was significantly higher in the two types of forests with developed understory vegetation in comparison with the forest without understory vegetation (One-way ANOVA, $F=27.32$, $\mathrm{df}=2,17, p<0.001$, Fig. 6). The differences among the three types of forest habitats remained when bird density was analyzed by season (Fig. 7 , Table 7 in Appendix). In spring, the difference in bird density between the three types of forest habitats narrowed and was not significant. In the summer, bird density in the DF habitat was similar to both NF and OF habitats.

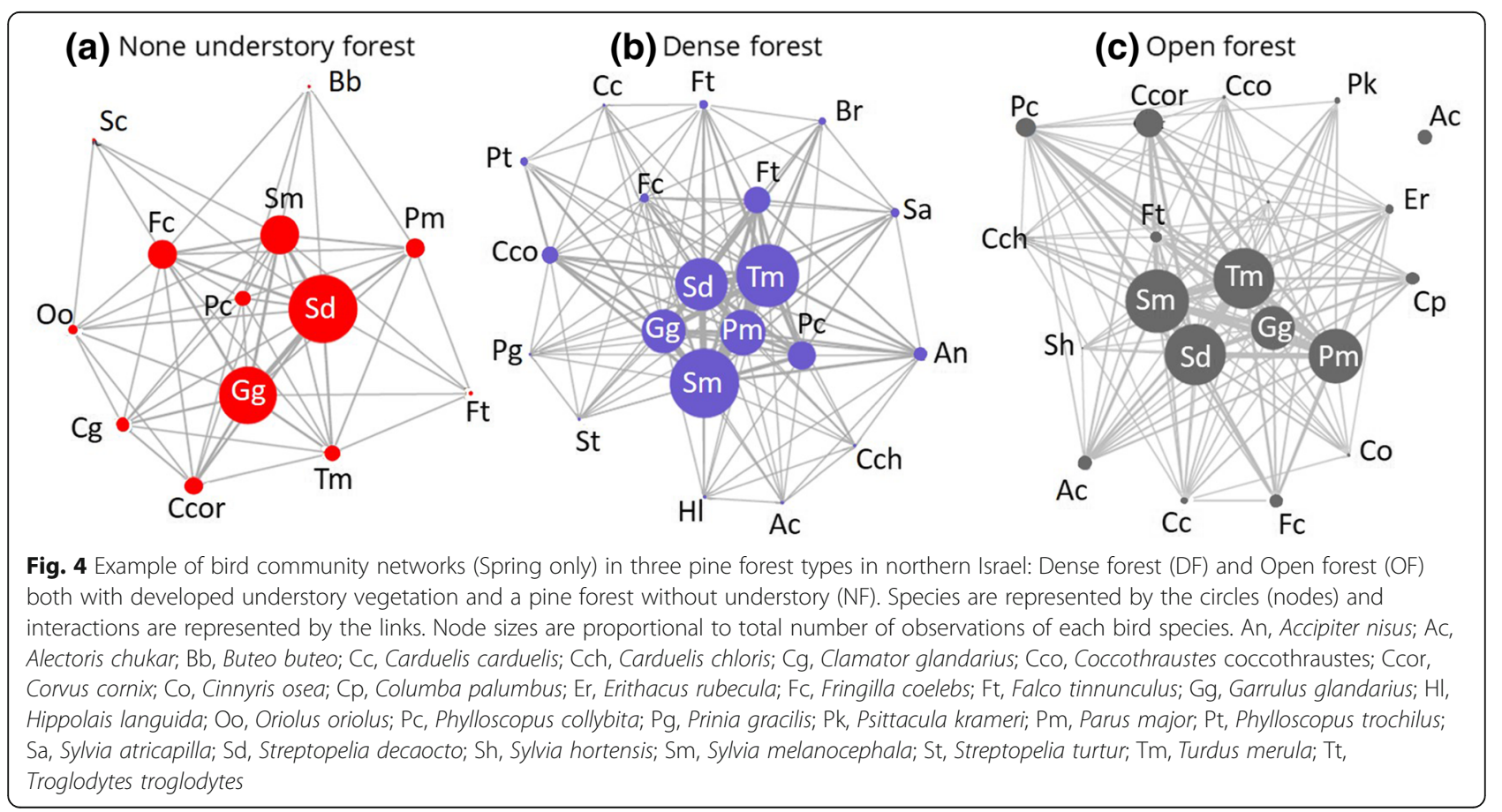


Table 1 The total numbers of the most common 10 bird species observed in the three types of forest habitats (normalized by number of visits per site, all seasons pooled)

\begin{tabular}{|c|c|c|c|c|c|}
\hline Species name & Common name & No understory forest & Dense forest & Open forest & Total \\
\hline Sylvia melanocephala & Sardinian warbler & $17^{a}$ & $185^{\mathrm{b}}$ & $196^{\mathrm{b}}$ & $459^{* *}$ \\
\hline Fringilla coelebs & Common chaffinch & 61 & 40 & 59 & 173 \\
\hline Turdus merula & Blackbird & $4^{\mathrm{a}}$ & $52^{\mathrm{b}}$ & $57^{b}$ & $130^{* *}$ \\
\hline Phylloscopus collybita & Chiffchaff & 21 & 43.5 & 48 & 127 \\
\hline Streptopelia decaocto & Collared dove & 31 & 28 & 47 & 115 \\
\hline Parus major & Great tit & $7^{a}$ & $37^{b}$ & $58^{\mathrm{b}}$ & $114^{*}$ \\
\hline Garrulus glandarius & Eurasian jay & 29 & 32 & 28 & 99 \\
\hline Erithacus rubecula & European robin & $0^{\mathrm{a}}$ & $22^{\mathrm{b}}$ & $34^{\mathrm{b}}$ & $65^{*}$ \\
\hline Columba palumbus & Common wood pigeon & 13 & 0 & 43 & 56 \\
\hline Corvus cornix & Hooded crow & 4 & 13 & 12 & 33 \\
\hline
\end{tabular}

$\left.{ }^{*}\right)$ significantly lower abundance, a $p$-value of $p<0.001$, in one-way ANOVA (different letters above bars indicate significant differences, Bonferroni Multiple Comparison Test, $p<0.05$ )

$(* *)$ significantly lower abundance, a $p$-value of $p<0.0006$, in one-way ANOVA (different letters above bars indicate significant differences, Bonferroni Multiple Comparison Test, $p<0.05$ )

However, in winter and fall both DF and OF habitats were significantly more dense in birds than the NF habitat (Fig. 7).

There were also significant differences in bird richness and diversity among the three types of habitat. Whereas the NF habitat was significantly lower in all indices of richness and diversity than the DF and OF habitats (Table 5 in Appendix), there was no significant difference in any index of richness and diversity between the DF and OF habitats (Table 2). The expected species accumulation curves (Fig. 8) in the three types of forest habitats were not reached a plateau; thus, more species are expected to be found with more bird surveys. The NF habitat had a significantly $(F=510.2$, $\mathrm{df}=2,147, p<0.001)$ lower species richness curve and the OF habitat had the highest curve. The expected richness of all three types of habitat together were higher than the curves of expected richness of each of the two DF and OF habitats. Furthermore, landscape gamma diversity of the three types of forests (33 bird species) was much higher than alpha diversity of each type of forest alone (Table 5 in Appendix).

\section{Discussion}

The structural difference among the three types of forest habitat

The three types of habitat that were studied can be categorized into two groups: one of the forest habitats had no understory (NF) whereas two of them (OF and DF) had a developed understory vegetation with $>100 \%$ vegetation cover. However, the $\mathrm{OF}$ and $\mathrm{DF}$ habitats were significantly different in their understory composition and pine density. It should be emphasized that since all of these forests were planted 50 to 56 years ago, there was no planned management that aimed to create various types of forest. The JNF current policy is to maintain sustainable management of forests that support high biodiversity and offer recreational and outdoor activity (Osem et al. 2014). Furthermore, the forests nowadays are barely treated (e.g., thinning, cutting, grazing) in recent decades. Thus, the development of the different types of forest habitats that we see today is mainly due to natural processes and fires rather than human planning.

The outcome is that these forests create a mosaic of heterogeneous habitats with high structural diversity of vegetation (Schall et al. 2018; Schulze et al. 2019). Consequently the heterogeneity among these three types of habitat will contribute to great richness and diversity across the whole landscape (Freemark and Merriam 1986; Brotons et al. 2005). Furthermore, a wide variety of vegetation is associated with the diversity of various fauna groups (Paillet et al. 2010; Irwin et al. 2014). Indeed, our study suggests that the combination of the three types of forest habitat also contributes to the overall richness and diversity of the bird community across the planted pine forests, as a mosaic-type forest landscape (Izhaki 2000).

\section{The impact of vegetation attributes on bird community structure}

It has been previously documented that birds are affected by the structure of forest vegetation (Huang et al. 2014; Ferger et al. 2014; Vogeler et al. 2014). The study plots of the three types of habitat were close to each other (the maximum distance between two study plots was $20 \mathrm{~km}$ ), located at the same altitude and in the same climatic zone, and had similar primary forest 

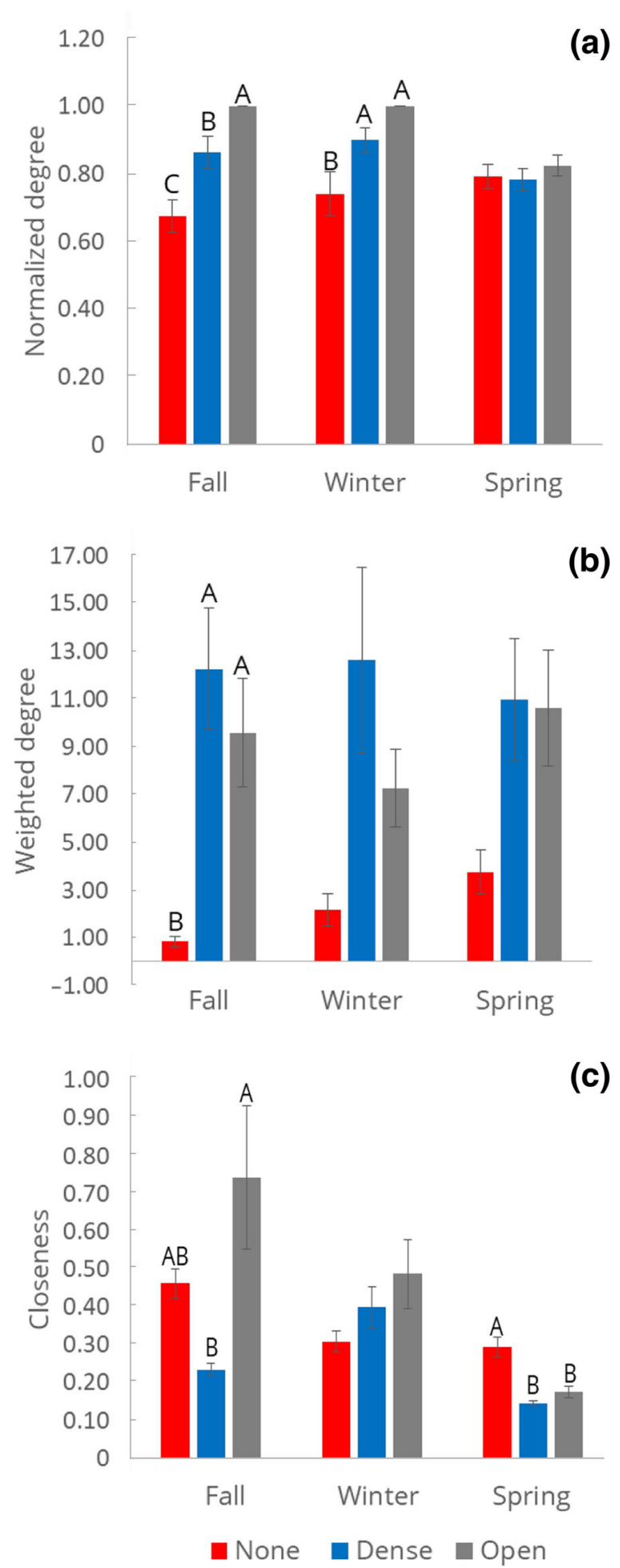

Fig. 5 Network complexity indices (Mean \pm S.E.) in the three forest types (NF in red, DF in blue, OF in gray) in each season using (a) interspecific interactions (normalized degree), b interaction frequency (weighted degree) and (c) distance among species (closeness). Different letter above bars followed significant ANOVA (Table 6 in Appendix) indicate significant differences (Bonferroni Multiple Comparison Test, $p<0.05$ ) plantations of the same age. Nonetheless, the results clearly demonstrate that at least two types of habitat (OF and DF) had a unique bird community and diversity in comparison to the third one (NF).

The main structural component of vegetation that had the highest influence on bird presence in this study was shrubs. Rhamnus lycioides, a very common Mediterranean spiny shrub, is one of the few woody shrub species that can establish itself in pine plantations (Moreno-Gutiérrez et al. 2015). Rhamnus lycioides, Pistacia lentiscus, Smilax aspera and Asparagus aphyllus are all produces edible fruits (during the fall and winter) and thus attracts frugivorous species, such as the Sardinian warbler and the Eurasian blackcap (Sylvia atricapilla) (Izhaki 2000). Gil-Tena et al. (2007) and Sweeney et al. (2010) reported similar results, demonstrating the importance of shrubs in the forest for bird refuge, foraging and breeding.

The understory is the key factor for the presence and abundance of several bird species. Great tit (Parus major) was significantly selective in our study, requiring a well-developed understory shrub layer. Similar results were reported by Díaz (2006) in Spanish woodlands and forests, where Great tit preferred mature pinewoods with developed understory vegetation. Similarly, in our study Blackbirds (Turdus merula) were totally absent from the NF habitat and preferred a highly developed understory shrub layer. This preference was also observed in the Western Mediterranean area of Spain (Díaz 2006) and in Switzerland (Von Dem et al. 2008).

The European robin (Erithacus rubecula) was also completely absent from the NF habitat in our study and preferred the OF habitat, which is practically a shrubland with sparse trees. Tellería and Perez-Tris (2004) showed a contrasting phenomenon, where this species preferred forests over shrubland, considering the forest as a nesting site and therefore as a strong territorial site. Our study showed that the understory creates a powerful microhabitat that attracts the European robin, and without this understory layer this forest would be rather empty of robins.

\section{Bird community complexity, richness, diversity and abundance in the three types of forest habitat}

The three types of forest habitat are significantly different in terms of network complexity, bird abundance, richness and diversity. The positive effect of vegetation heterogeneity on forest and woodland bird species richness is well established in studies across the world (Koh et al. 2006; Davies et al. 2007; Huang et al. 2014). The NF habitat in this study lacks understory vegetation and therefore represents a homogenous rather than heterogeneous forest. Consequently, the NF habitat maintains lower bird species richness as well as much lower community complexity, as in monoculture forests (Erskine et al. 2006). The difference 


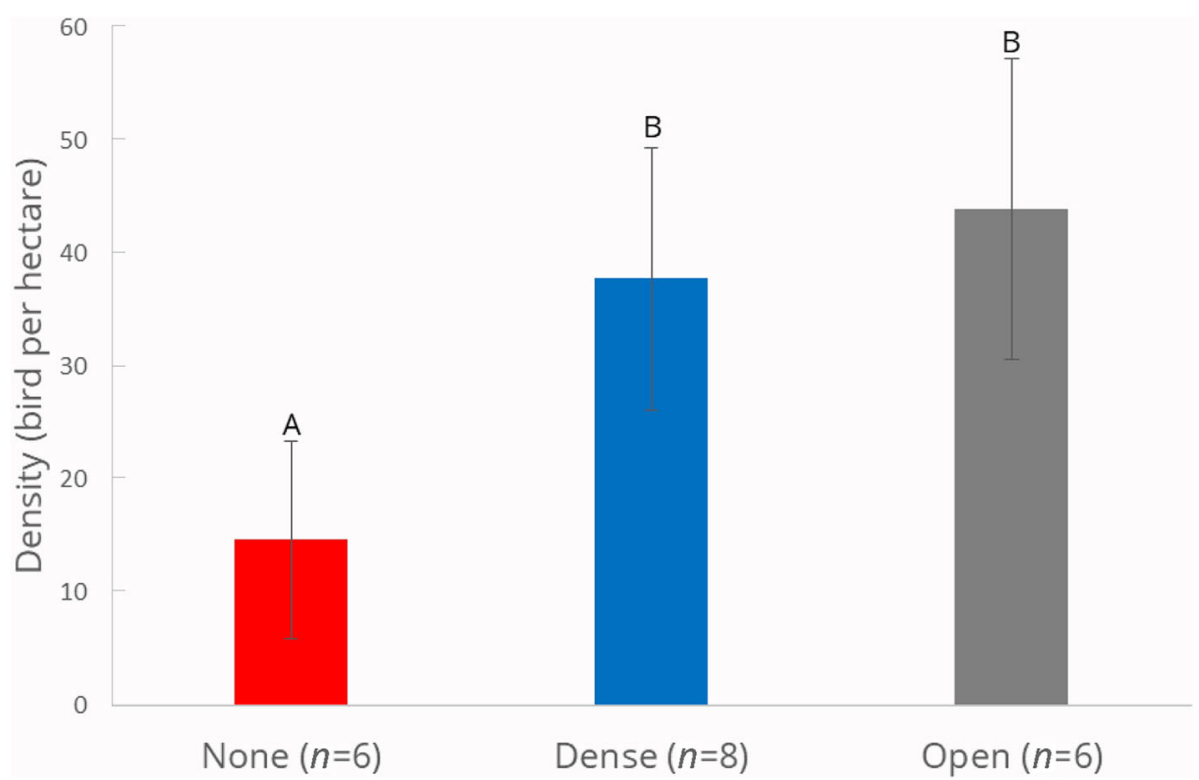

Fig. 6 Total bird density per ha (mean \pm SE) in the three forest habitats. Higher bird density was found in the Dense forest (DF in blue) and Open forest (OF in gray) habitats in comparison with the No understory (NF in red) habitat (different letters above bars indicate significant differences, Bonferroni Multiple Comparison Test, $p<0.05)$

(a) Fall

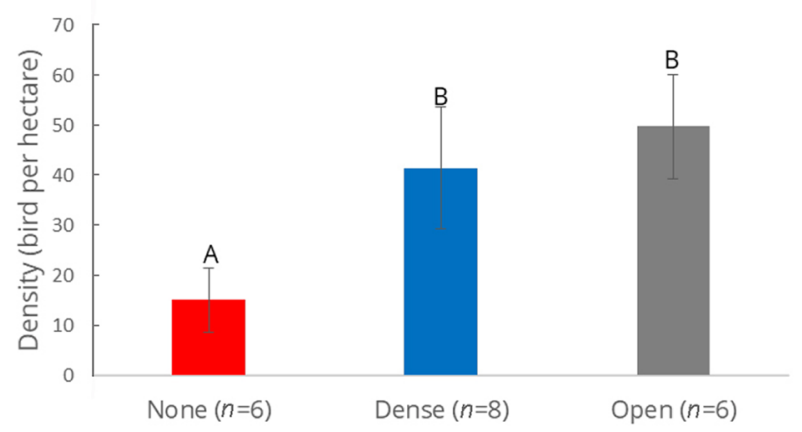

(c) Spring

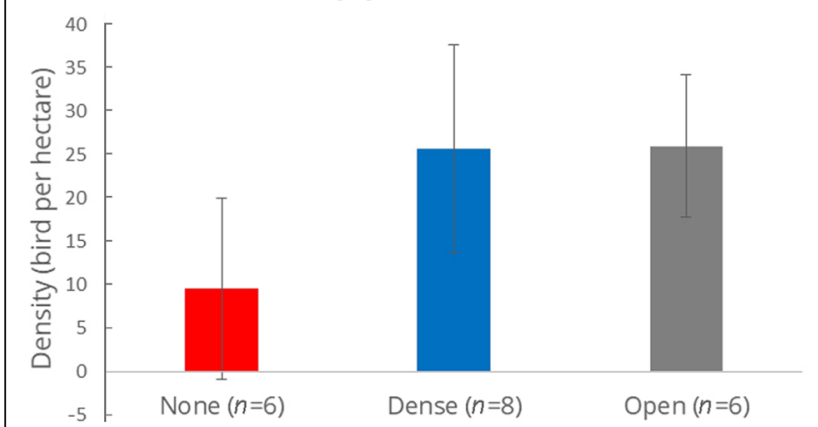

(b) Winter

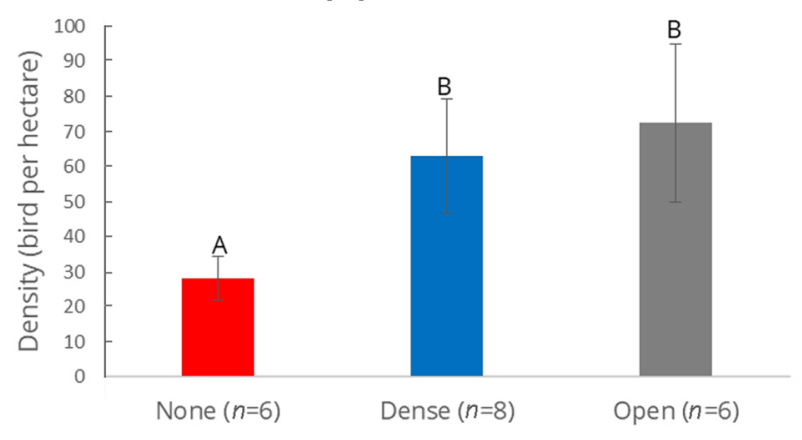

(d) Summer

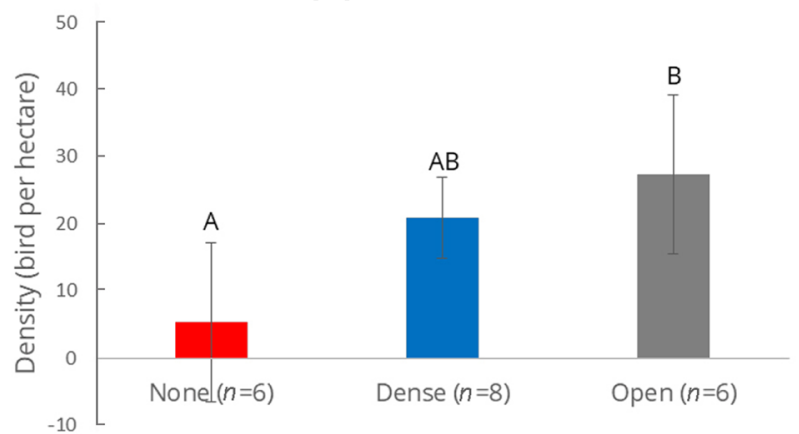

Fig. 7 Bird density per ha (mean \pm SE) in the three types of forest habitat, per season higher bird density was found in the Dense forest (blue) and Open forest (gray) habitats in comparison with the No understory (red) forest habitat (different letters above bars indicate significant differences (Bonferroni Multiple Comparison Test, $p<0.05$ ) 
Table 2 Bird diversity and abundance scores in the three types of forest habitat (all seasons pooled)

\begin{tabular}{|c|c|c|c|c|c|c|}
\hline & Average abundance (per visit) & Density (birds per ha) & Chao index & Expected richness & Total number of individuals & Visits \\
\hline$\overline{N F}$ & $4.2^{\mathrm{a}}$ & $15.4^{\mathrm{a}}$ & $11.2^{a}$ & $15.7^{\mathrm{a}}$ & $197^{\mathrm{a}}$ & 52 \\
\hline DF & $11.6^{\mathrm{b}}$ & $38.2^{b}$ & $16.9^{b}$ & $20.5^{b}$ & $658^{b}$ & 72 \\
\hline OF & $13.7^{b}$ & $43.8^{b}$ & $16.8^{b}$ & $22.0^{b}$ & $613^{b}$ & 56 \\
\hline$F$ & 21.7 & 4 & 10.7 & 10.2 & 8.5 & \\
\hline df (degrees of freedom) & 2 & 2 & 2 & 2 & 2 & \\
\hline$p^{*}$ & $<0.001$ & $<0.03$ & $<0.001$ & $<0.001$ & $<0.001$ & \\
\hline
\end{tabular}

*One-way ANOVA (different letters above bars indicate significant differences, Bonferroni Multiple Comparison Test, $p<0.05$ )

between a monoculture forest and a monoculture forest with well-developed understory vegetation was also a key factor affecting species richness in other studies (Lugo 1997; Azor et al. 2015). Likewise, in the OF and DF habitats, where the understory vegetation is well developed, we found more bird species and higher diversity.

The age of the pine forest can be a contributing factor to bird species richness through the development of the understory layer over time (Hobson and Bayne 2000; Díaz 2006; Gil-Tena et al. 2007). However, in the current study, although the plantation time of all forest plots was similar, a marked difference in the growth of the understory vegetation was observed among the three types of habitat. Therefore, we were able to examine the impact of understory vegetation on bird species richness while controlling for forest age.

Plots with developed understory vegetation plots showed significantly high diversity, similar to the results of other studies (Izhaki 2000; Nilsson and Wardle 2005).

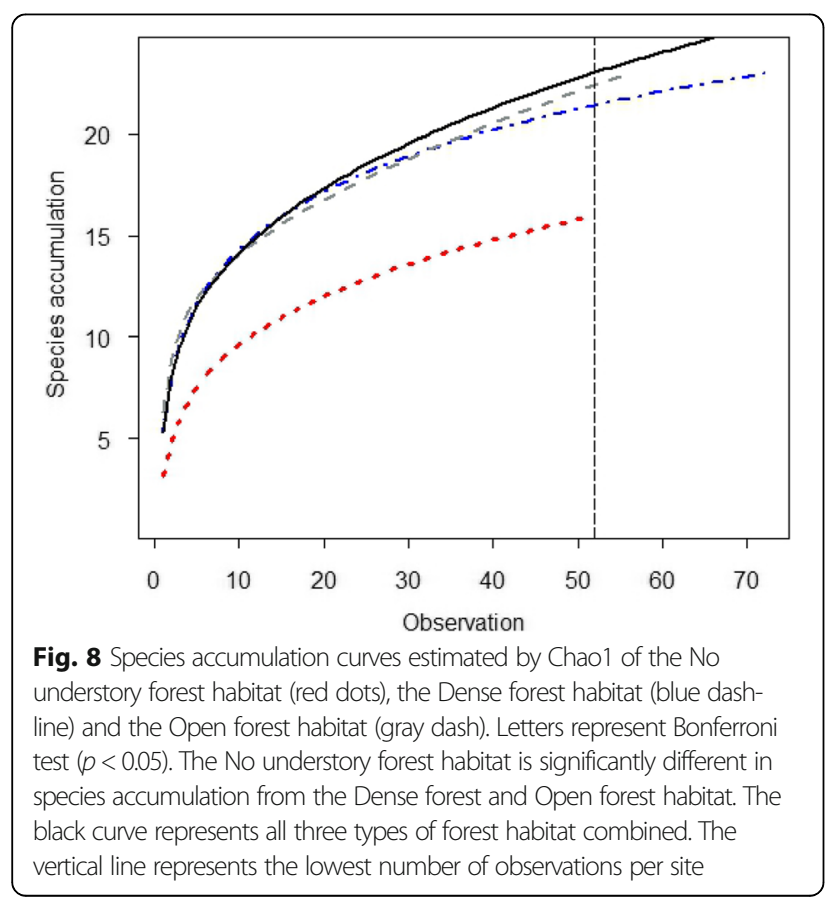

The growth of shrubs and young trees seems to appeal to birds in our study area. The wild, dense evergreen woodland in the Mediterranean basin is based primarily on low trees and shrubs (Perevolotsky and Haimov 1992). Therefore, most of the birds observed in this study were typical to wild shrublands and dense woodlands. For example, the Sardinian warbler (Bas et al. 2005), which normally avoids pine plantations (Rey-Benayas et al. 2010), was observed numerous times in this study in the pine forests, mostly in forest plots with rich understory.

\section{Conclusions}

Indeed, managed forest in sustainable matter can provide both wood for human uses rich biodiversity (Liang et al. 2016). But, since the industrial forestry in Israel was not successful, it is unfortunate that some of the ecological services from pine forest are not provided, and moreover, import from wood from other forests is forced.

A shrub layer provides food diversity, refuge and breeding sites by increasing the heterogeneity of the forest habitat (Izhaki 2000; Bonham et al. 2002; Díaz 2006; Sweeney et al. 2010). Vegetation cover under the canopy of the forest is key to the increase in species diversity and richness (Kirk and Hobson 2001; Ross et al. 2001; Herrando and Brotons 2002; Golet et al. 2001). The past management of industry forests dramatically reduced the understory and produced an almost "green desert" forest (Dyer et al. 2004). We suggest that the natural succession in planted pine forests, such as seed dispersal by birds, should be encouraged, as long as no timber production is expected in the future from these pine trees. We also recommend that forest managers actively promote understory vegetation by thinning the pine forest and allowing understory vegetation to establish. Such a management policy will create heterogeneous seminatural forests that maintain high biodiversity, instead of the originally planned monoculture of pine forests for the industry. 


\section{Appendix}

Table 3 Parameters used to characterize the habitat structure of each of three types of forest habitats

\begin{tabular}{|c|c|c|c|c|c|c|}
\hline \multirow[t]{2}{*}{ Parameter } & \multicolumn{2}{|c|}{$\begin{array}{l}\text { No understory } \\
\text { forest } \\
(n=6)\end{array}$} & \multicolumn{2}{|c|}{$\begin{array}{l}\text { Dense forest } \\
(n=8)\end{array}$} & \multicolumn{2}{|c|}{$\begin{array}{l}\text { Open forest } \\
(n=6)\end{array}$} \\
\hline & Average & SD & Average & SD & Average & SD \\
\hline $\begin{array}{l}\text { Soil (cover } \\
\text { percentage) }\end{array}$ & $12.09 \%$ & $11.47 \%$ & $13.86 \%$ & $9.09 \%$ & $15.37 \%$ & $14.54 \%$ \\
\hline $\begin{array}{l}\text { Low trees } \\
\text { (cover } \\
\text { percentage) }\end{array}$ & 0 & 0 & $65.11 \%$ & $98.14 \%$ & $35.28 \%$ & $45.97 \%$ \\
\hline $\begin{array}{l}\text { Shrubs (cover } \\
\text { percentage) }\end{array}$ & $0.73 \%$ & $1.64 \%$ & $119.49 \%$ & $56.23 \%$ & $111.92 \%$ & $26.77 \%$ \\
\hline $\begin{array}{l}\text { Total } \\
\text { vegetation } \\
\text { (cover } \\
\text { percentage) }\end{array}$ & $12.83 \%$ & $11.72 \%$ & $198.46 \%$ & $128.29 \%$ & $162.57 \%$ & $52.75 \%$ \\
\hline Trees per ha & 1100.00 & 412.31 & 1525.00 & 263.39 & 366.67 & 137.44 \\
\hline $\begin{array}{l}\text { Average tree } \\
\text { height }(m)\end{array}$ & 18.57 & 1.91 & 17.25 & 2.34 & 16.66 & 2.02 \\
\hline $\begin{array}{l}\text { Average tree } \\
\text { volume }(\mathrm{cm})\end{array}$ & 96.93 & 12.31 & 91.82 & 7.42 & 103.37 & $0.28 \%$ \\
\hline $\begin{array}{l}\text { Smilax aspera } \\
\text { (cover } \\
\text { percentage) }\end{array}$ & $2.78 \%$ & $4.47 \%$ & $58.03 \%$ & $34.61 \%$ & $24.79 \%$ & $39.17 \%$ \\
\hline $\begin{array}{l}\text { Asparagus } \\
\text { aphyllus (cover } \\
\text { percentage) }\end{array}$ & $5.75 \%$ & $12.75 \%$ & $29.95 \%$ & $34.93 \%$ & $2.53 \%$ & $2.10 \%$ \\
\hline $\begin{array}{l}\text { Pistacia } \\
\text { lentiscus (cover } \\
\text { percentage) }\end{array}$ & $0.24 \%$ & $0.54 \%$ & $60.76 \%$ & $48.29 \%$ & $26.26 \%$ & $28.50 \%$ \\
\hline $\begin{array}{l}\text { Rhamnus } \\
\text { lycioides (cover } \\
\text { percentage) }\end{array}$ & $2.25 \%$ & $3.88 \%$ & $25.50 \%$ & $22.16 \%$ & $61.93 \%$ & $43.06 \%$ \\
\hline
\end{tabular}

Table 4 The correlation between the habitat structure parameters and the standardized canonical discriminant functions. Parameters ordered by absolute size of correlation within function

\begin{tabular}{lll}
\hline & Function & \\
\cline { 2 - 3 } & 1 & 2 \\
\hline Other shrubs coverage & -0.431 & 0.354 \\
Rhamnus coverage & -0.299 & -0.101 \\
Tree height & 0.129 & -0.026 \\
Soil coverage & -0.039 & -0.003 \\
Trees per hectare & 0.306 & 0.727 \\
Smilax coverage & -0.125 & 0.345 \\
Pistacia coverage & -0.130 & 0.331 \\
Asparagus coverage & 0 & 0.280 \\
Tree volume & -0.067 & -0.194 \\
Low trees & -0.086 & 0.167 \\
\hline
\end{tabular}

Table 5 Total number and diversity indices (Alpha and Gamma) of birds observed in each type of forest habitat during the study (all seasons pooled)

\begin{tabular}{|c|c|c|c|c|}
\hline Species name & $\begin{array}{l}\text { Dense } \\
\text { forest (DF) }\end{array}$ & $\begin{array}{l}\text { No understory } \\
\text { forest (NF) }\end{array}$ & $\begin{array}{l}\text { Open } \\
\text { forest (OF) }\end{array}$ & Total \\
\hline Accipiter nisus & 10 & 1 & 1 & 12 \\
\hline Alectoris chukar & 10 & 0 & 9 & 19 \\
\hline Aquila pomarina & 1 & 1 & 0 & 2 \\
\hline Buteo buteo & 0 & 1 & 1 & 2 \\
\hline Carduelis carduelis & 1 & 0 & 2 & 3 \\
\hline Carduelis chloris & 4 & 0 & 4 & 8 \\
\hline Cinnyris osea & 0 & 0 & 1 & 1 \\
\hline Clamator glandarius & 0 & 3 & 0 & 3 \\
\hline $\begin{array}{l}\text { Coccothraustes } \\
\text { coccothraustes }\end{array}$ & 0 & 0 & 1 & 1 \\
\hline Columba palumbus & 0 & 13 & 43 & 56 \\
\hline Corvus cornix & 17 & 4 & 12 & 33 \\
\hline Erithacus rubecula & 31 & 0 & 34 & 65 \\
\hline Falco subbuteo & 2 & 0 & 0 & 2 \\
\hline Falco tinnunculus & 4 & 1 & 6 & 11 \\
\hline Fringilla coelebs & 53 & 61 & 59 & 173 \\
\hline Garrulus glandarius & 42 & 29 & 28 & 99 \\
\hline Hippolais languida & 1 & 0 & 0 & 1 \\
\hline Oriolus oriolus & 0 & 2 & 0 & 2 \\
\hline Parus major & 49 & 7 & 58 & 114 \\
\hline Phylloscopus collybita & 58 & 21 & 48 & 127 \\
\hline Phylloscopus trochilus & 6 & 0 & 0 & 6 \\
\hline Prinia gracilis & 1 & 0 & 0 & 1 \\
\hline Psittacula krameri & 0 & 0 & 2 & 2 \\
\hline Scolopax rusticola & 2 & 0 & 0 & 2 \\
\hline Streptopelia decaocto & 37 & 31 & 47 & 115 \\
\hline Streptopelia turtur & 1 & 0 & 0 & 1 \\
\hline Sylvia atricapilla & 3 & 0 & 1 & 4 \\
\hline Sylvia curruca & 0 & 1 & 0 & 1 \\
\hline Sylvia hortensis & 0 & 0 & 1 & 1 \\
\hline Sylvia melanocephala & 246 & 17 & 196 & 459 \\
\hline Troglodytes troglodytes & 10 & 0 & 1 & 11 \\
\hline Turdus merula & 69 & 4 & 57 & 130 \\
\hline Turdus philomelos & 0 & 0 & 1 & 1 \\
\hline Total & 658 & 205 & 613 & 1476 \\
\hline Alpha Diversity & 23 & 16 & 23 & \\
\hline Gamma Diversity & & & & 33 \\
\hline
\end{tabular}


Table 6 The results of the MNDS ordination analysis of bird communities in relation to habitat structure (Fig. 3)

\begin{tabular}{lllll}
\hline & NMDS1 & NMDS2 & $r^{2}$ & $P$ \\
\hline Low vegetation cover & -0.2013 & 0.97953 & 0.3071 & 0.043 \\
Low tree cover & -0.78272 & 0.62238 & 0.1066 & 0.319 \\
Shrubs cover & -0.97886 & -0.20451 & 0.5362 & 0.001 \\
Total vegetation cover & -0.98254 & 0.18607 & 0.3777 & 0.024 \\
Trees per ha & 0.10147 & 0.99484 & 0.0434 & 0.701 \\
Tree height & 0.37536 & 0.92688 & 0.1854 & 0.18 \\
Tree volume & -0.97843 & 0.20659 & 0.0032 & 0.972 \\
Smilax aspera cover & -0.90532 & -0.42473 & 0.3133 & 0.047 \\
Pistacia lentiscus cover & -0.8954 & 0.44525 & 0.2221 & 0.107 \\
Rhamnus lycioides cover & -0.56554 & -0.82472 & 0.3504 & 0.028 \\
Asparagus aphyllus cover & -0.63062 & 0.77609 & 0.1585 & 0.210 \\
\hline
\end{tabular}

Table 7 The effect of pine forest types in northern Israel (Dense forest, DF and Open forest, OF, both with developed understory vegetation and a pine forest without understory, NF) on the three complexity indices in each season using ANOVA

\begin{tabular}{|c|c|c|c|c|c|c|}
\hline \multirow{2}{*}{\multicolumn{2}{|c|}{$\frac{\text { Season }}{\text { Normalized degree }}$}} & \multirow[t]{2}{*}{ Type III sum of squares } & \multirow[t]{2}{*}{$\mathrm{df}$} & \multirow[t]{2}{*}{ Mean square } & \multirow[t]{2}{*}{$F$} & \multirow[t]{2}{*}{ Sig. } \\
\hline & & & & & & \\
\hline \multirow[t]{6}{*}{ Fall } & Corrected model & $0.486^{b}$ & 2 & 0.243 & 15.616 & 0.000 \\
\hline & Intercept & 21.552 & 1 & 21.552 & 1383.898 & 0.000 \\
\hline & Habitat & 0.486 & 2 & 0.243 & 15.616 & 0.000 \\
\hline & Error & 0.436 & 28 & 0.016 & & \\
\hline & Total & 24.042 & 31 & & & \\
\hline & Corrected total & 0.922 & 30 & & & \\
\hline \multirow[t]{6}{*}{ Spring } & Corrected model & $0.018^{c}$ & 2 & 0.009 & 0.471 & 0.627 \\
\hline & Intercept & 32.062 & 1 & 32.062 & 1663.980 & 0.000 \\
\hline & Habitat & 0.018 & 2 & 0.009 & 0.471 & 0.627 \\
\hline & Error & 0.944 & 49 & 0.019 & & \\
\hline & Total & 34.268 & 52 & & & \\
\hline & Corrected total & 0.962 & 51 & & & \\
\hline \multirow[t]{6}{*}{ Winter } & Corrected model & $0.262^{d}$ & 2 & 0.131 & 12.842 & 0.000 \\
\hline & Intercept & 19.497 & 1 & 19.497 & 1910.898 & 0.000 \\
\hline & Habitat & 0.262 & 2 & 0.131 & 12.842 & 0.000 \\
\hline & Error & 0.245 & 24 & 0.010 & & \\
\hline & Total & 22.634 & 27 & & & \\
\hline & Corrected total & 0.507 & 26 & & & \\
\hline \multicolumn{7}{|c|}{ Weighted degree } \\
\hline \multirow[t]{6}{*}{ Fall } & Corrected model & $649.161^{b}$ & 2 & 324.581 & 6.349 & 0.005 \\
\hline & Intercept & 1722.839 & 1 & 1722.839 & 33.700 & 0.000 \\
\hline & Habitat & 649.161 & 2 & 324.581 & 6.349 & 0.005 \\
\hline & Error & 1431.442 & 28 & 51.123 & & \\
\hline & Total & 4251.940 & 31 & & & \\
\hline & Corrected total & 2080.603 & 30 & & & \\
\hline \multirow[t]{2}{*}{ Spring } & Corrected model & $482.364^{c}$ & 2 & 241.182 & 2.533 & 0.090 \\
\hline & Intercept & 3587.223 & 1 & 3587.223 & 37.680 & 0.000 \\
\hline
\end{tabular}


Table 7 The effect of pine forest types in northern Israel (Dense forest, DF and Open forest, OF, both with developed understory vegetation and a pine forest without understory, NF) on the three complexity indices in each season using ANOVA (Continued)

\begin{tabular}{|c|c|c|c|c|c|c|}
\hline \multicolumn{2}{|l|}{ Season } & \multirow{2}{*}{$\begin{array}{l}\text { Type III sum of squares } \\
482.364\end{array}$} & \multirow{2}{*}{$\frac{\mathrm{df}}{2}$} & \multirow{2}{*}{$\frac{\text { Mean square }}{241.182}$} & \multirow{2}{*}{$\frac{F}{2.533}$} & \multirow{2}{*}{$\frac{\text { Sig. }}{0.090}$} \\
\hline & Habitat & & & & & \\
\hline & Error & 4664.930 & 49 & 95.203 & & \\
\hline & Total & 9404.414 & 52 & & & \\
\hline & Corrected total & 5147.294 & 51 & & & \\
\hline \multirow[t]{6}{*}{ Winter } & Corrected model & $422.295^{d}$ & 2 & 211.147 & 3.049 & 0.066 \\
\hline & Intercept & 1364.453 & 1 & 1364.453 & 19.706 & 0.000 \\
\hline & Habitat & 422.295 & 2 & 211.147 & 3.049 & 0.066 \\
\hline & Error & 1661.778 & 24 & 69.241 & & \\
\hline & Total & 3867.003 & 27 & & & \\
\hline & Corrected total & 2084.073 & 26 & & & \\
\hline \multicolumn{7}{|l|}{ Closeness } \\
\hline \multirow[t]{6}{*}{ Fall } & Corrected model & $1.477^{b}$ & 2 & 0.739 & 5.068 & 0.013 \\
\hline & Intercept & 6.915 & 1 & 6.915 & 47.442 & 0.000 \\
\hline & Habitat & 1.477 & 2 & 0.739 & 5.068 & 0.013 \\
\hline & Error & 4.081 & 28 & 0.146 & & \\
\hline & Total & 12.500 & 31 & & & \\
\hline & Corrected total & 5.558 & 30 & & & \\
\hline \multirow[t]{6}{*}{ Spring } & Corrected model & $0.184^{c}$ & 2 & 0.092 & 21.695 & 0.000 \\
\hline & Intercept & 2.106 & 1 & 2.106 & 497.332 & 0.000 \\
\hline & Habitat & 0.184 & 2 & 0.092 & 21.695 & 0.000 \\
\hline & Error & 0.207 & 49 & 0.004 & & \\
\hline & Total & 2.339 & 52 & & & \\
\hline & Corrected total & 0.391 & 51 & & & \\
\hline \multirow[t]{6}{*}{ Winter } & Corrected model & $0.127^{d}$ & 2 & 0.063 & 1.267 & 0.300 \\
\hline & Intercept & 3.995 & 1 & 3.995 & 80.016 & 0.000 \\
\hline & Habitat & 0.127 & 2 & 0.063 & 1.267 & 0.300 \\
\hline & Error & 1.198 & 24 & 0.050 & & \\
\hline & Total & 5.972 & 27 & & & \\
\hline & Corrected total & 1.325 & 26 & & & \\
\hline
\end{tabular}

\section{Abbreviations}

DF: Dense pine forest with a diverse understory of shrubs and shrub-like trees; NF: Dense pine forest with (almost) no understory except herbaceous vegetation; OF: Open pine forest with natural broadleaf trees and an understory of large shrubs

\section{Acknowledgements}

Not applicable.

\section{Funding}

This study was supported by a grant from the Jewish National Fund (KKL, grant no. 60-05-095-14).

\section{Availability of data and materials}

The datasets used and/or analyzed during the current study are available from the corresponding author on reasonable request.

\section{Authors' contributions}

UD and II designed the study. UD collected all the data. UD and II analyzed the data and wrote the manuscript together. Both authors read and approved the final manuscript.
Ethics approval and consent to participate

Not applicable.

\section{Consent for publication}

Not applicable.

\section{Competing interests}

The authors declare that they have no competing interests.

Received: 22 December 2018 Accepted: 6 May 2019

Published online: 05 June 2019

\section{References}

A.C. Smith, P.A. Harrison, M. Pérez Soba, F. Archaux, M. Blicharska, B.N. Egoh, T. Erős, N. Fabrega Domenech, Á.l. György, R. Haines-Young, S. Li, E.Lommelen, L. Meiresonne, L. Miguel Ayala, L. Mononen, G. Simpson, E. Stange, F. Turkelboom, M. Uiterwijk, C.J. Veerkamp, V. Wyllie de Echeverria, (2017) How natural capital delivers ecosystem services: A typology derived from a systematic review. Ecosystem Services 26:111-126 
Alldredge MW, Pollock KH, Simons TR, Shriner SA (2007) Multiple-species analysis of point count data: a more parsimonious modelling framework. J Appl Ecol 44:281-290. https://doi.org/10.1111/j.1365-2664. 2006.01271.x

Azor JS, Santos X, Pleguezuelos JM (2015) Conifer-plantation thinning restores reptile biodiversity in Mediterranean landscapes. Forest Ecol Manag 354:185189. https://doi.org/10.1016/j.foreco.2015.06.020

Bas JM, Pons P, Gómez C (2005) Home range and territory of the Sardinian warbler Sylvia melanocephala in Mediterranean shrubland. Bird Study 52:137144. https://doi.org/10.1080/00063650509461383

Bibby CJ (2000) Bird Census Techniques. Elsevier, Amsterdam

Bock C, Jones Z (2004) Avian habitat evaluation: should counting birds count? Front Ecol Environ 2:403-410

Bolund P, Hunhammar S (1999) Ecosystem services in urban areas. Ecol Econ 29: 293-301. https://doi.org/10.1016/S0921-8009(99)00013-0

Boneh $\mathrm{O}$ (2015) Changing in forest management in the Mediterranean region of Israel: form mono-species and single-age forest to mixed multi-ages forest (in Hebrew). Yaar 14:5-14

Bonham KJ, Mesibov R, Bashford R (2002) Diversity and abundance of some ground-dwelling invertebrates in plantation vs. native forests in Tasmania Australia. Forest Ecol Manag 158:237-247. https://doi.org/10.1016/S03781127(00)00717-9

Brockerhoff EG, Jactel H, Parrotta JA, Quine CP, Sayer J (2008) Plantation forests and biodiversity: oxymoron or opportunity? Biodivers Conserv 17:925-951. https://doi.org/10.1007/s10531-008-9380-x

Brotons L, Herrando S, Martin J-L (2005) Bird assemblages in forest fragments within Mediterranean mosaics created by wild fires. Landsc Ecol 19:663-675. https://doi.org/10.1007/s10980-005-0165-2

Brown DJ, Ferrato JR, White CJ, Mali I, Forstner MRJ, Simpson TR (2015) Shortterm changes in summer and winter resident bird communities following a high severity wildfire in a southern USA mixed pine/hardwood forest. Forest Ecol Manag 350:13-21. https://doi.org/10.1016/j.foreco.2015.04.017

Buckland ST, Marsden SJ, Green RE (2008) Estimating bird abundance: making methods work. Bird Conserv Int 18:S91-S108. https://doi.org/10.1017/ S0959270908000294

Canterbury G, Martin T, Petit D (2000) Bird communities and habitat as ecological indicators of forest condition in regional monitoring. Conserv Biol 14:544-558

Carignan V, Villard M-A (2002) Selecting indicator species to monitor ecological integrity: a review. Environ Monit Assess 78:45-61. https://doi.org/10.1023/A:1016136723584

CBS - statistical abstract of Israel (2014) Forest, planted forest area. http://www. cbs.gov.il/reader/shnaton/templ_shnaton.html?num_tab=st19_07\&CYear= 2014. Accessed 26 Aug 2018

Csardi G, Nepusz T (2006), The igraph software package for complex network research. InterJournal (Complex Systems).

Czeszczewik D, Zub K, Stanski T, Sahel M, Kapusta A, Walankiewicz W (2015) Effects of forest management on bird assemblages in the Bialowieza Forest, Poland iForest - Biogeosciences For, vol 8, pp 377-385. https://doi.org/10. 3832/ifor1212-007

Daily GC, Ehrlich PR, Haddad NM (1993) Double keystone bird in a keystone species complex. P Natl A Sci 90:592-594

Davies RG, Orme CDL, Storch D, Olson VA, Thomas GH, Ross SG, Ding T-S, Rasmussen PC, Bennett PM, Owens IPF, Blackburn TM, Gaston KJ (2007) Topography, energy and the global distribution of bird species richness. Proceedings Biol Sci 274:1189-1197. https://doi.org/10.1098/rspb.2007.0046

Díaz $L$ (2006) Influences of forest type and forest structure on bird communities in oak and pine woodlands in Spain. Forest Ecol Manag 223:54-65. https:// doi.org/10.1016/j.foreco.2005.10.061

Dufour-Dror, JM (2005) The significance of dense sclerophyllous oak forests in the landscapes of northern Israel and their ecological values: An unconventional viewpoint. Israel Journal of Plant Sciences 53 (3):215-224

Dray S, Dufour AB (2007) The ade4 package: implementing the duality diagram for ecologists. J Stat Softw 22:1-20 10.1.1.177.8850

Dyer LA, Letourneau DK, Dodson CD, Tobler MA, Stireman JO, Hsu A (2004) Ecological causes and consequences of variation in defensive chemistry of a neotropical shrub. Ecology 85:2795-2803. https://doi. org/10.2307/3450438

Ellis TM, Betts MG (2011) Bird abundance and diversity across a hardwood gradient within early seral plantation forest. Forest Ecol Manag 261 1372-1381. https://doi.org/10.1016/j.foreco.2011.01.018
Erskine PD, Lamb D, Bristow M (2006) Tree species diversity and ecosystem function: can tropical multi-species plantations generate greater productivity? Forest Ecol Manag 233:205-210. https://doi.org/10.1016/j.foreco.2006.05.013

Ferger SW, Schleuning M, Hemp A, Howell KM, Böhning-Gaese K (2014) Food resources and vegetation structure mediate climatic effects on species richness of birds. Glob Ecol Biogeogr 23:541-549. https://doi.org/10.1111/ geb.12151

Fox TR (2000) Sustained productivity in intensively managed forest plantations. Forest Ecol Manag 138:187-202. https://doi.org/10.1016/S03781127(00)00396-0

Freemark K, Merriam HG (1986) Importance of area and habitat heterogeneity to bird assemblages in temperate forest fragments. Biol Conserv 36:115-141. https://doi.org/10.1016/0006-3207(86)90002-9

Fuller RJ (2003) Bird life of woodland and forest. Cambridge University Press, Cambridge

Fuller RJ, Smith KW, Grice PV, Currie FA, Quine CP (2007) Habitat change and woodland birds in Britain: implications for management and future research. Ibis (Lond 1859) 149:261-268. https://doi.org/10.1111/j.1474-919X. 2007.00775.x

Gil-Tena A, Saura S, Brotons L (2007) Effects of forest composition and structure on bird species richness in a Mediterranean context: implications for forest ecosystem management. Forest Ecol Manag 242:470-476. https://doi.org/10. 1016/j.foreco.2007.01.080

Goldreich Y (1994) The spatial distribution of annual rainfall in Israel - a review. Theor Appl Climatol 50:45-59. https://doi.org/10.1007/BF00864902

Golet FC, Wang Y, Merrow JS, DeRagon WR (2001) Relationship between habitat and landscape features and the avian community of red maple swamps in southern Rhode Island. Wilson Bull 113:217-227. https://doi.org/10.1676/ 0043-5643(2001)113[0217:RBHALF]2.0.CO;2

Gregory R (2006) Birds as biodiversity indicators for Europe. Significance 3:106110. https://doi.org/10.1111/j.1740-9713.2006.00178.x

Gregory RD, Noble D, Field R, Marchant J, Raven M, Gibbons DW (2003) Using birds as indicators of biodiversity. Ornis Hung 12-13:11-24

Hansen AJ, Spies TA, Swanson FJ, Ohmann JL (1991) Conserving biodiversity in managed forests. Bioscience 41:382-392

Harris LD (1984) The fragmented forest: island biogeography theory and the preservation of biotic diversity. University of Chicago Press, Chieago

Herrando S, Brotons L (2002) Forest bird diversity in Mediterranean areas affected by wildfires: a multi-scale approach. Ecography (Cop) 25:161-172. https://doi. org/10.1034/j.1600-0587.2002.250204.x

Hobson KA, Bayne E (2000) The effects of stand age on avian communities in aspen-dominated forests of Central Saskatchewan, Canada. Forest Ecol Manag 136:121-134. https://doi.org/10.1016/S0378-1127(99)00287-X

Huang Q, Swatantran A, Dubayah R, Goetz SJ (2014) The influence of vegetation height heterogeneity on forest and woodland bird species richness across the United States. PLoS One 9:e103236

Huff MH, Bettinger KA, Ferguson HL, Brown MJ, Altman B (2000) A habitat-based point-count protocol for terrestrial birds, emphasizing Washington and Oregon. Gen Tech Rep PNW-GTR-501:39

Irwin S, Pedley SM, Coote L, Dietzsch AC, Wilson MW, Oxbrough A, Sweeney O, Moore KM, Martin R, Kelly DL, Mitchell FJG, Kelly TC, O'Halloran J (2014) The value of plantation forests for plant, invertebrate and bird diversity and the potential for cross-taxon surrogacy. Biodivers Conserv 23:697-714. https://doi. org/10.1007/s10531-014-0627-4

Izhaki I (2000) Passerine bird communities in Mediterranean pine forests. In: Ne'eman G, Trabaud L (eds) Ecology, Biogeography and Management of Pinus hiaepensis and P. brutia Forest Ecosystems in the Mediterranean Basin. Backhuys Publisher, Leiden, pp 237-250

Izhaki I, Adar M (1997) The effects of post-fire management on bird community succession. Int J Wildland Fire 7:335. https://doi.org/10.1071/WF9970335

JNF (2014) JNF forests data to 2014. http://www.kkl.org.il/afforestation-andenvironment/afforestation/forest-data/. Accessed 26 Aug 2018.

Kirk DA, Hobson KA (2001) Bird-habitat relationships in jack pine boreal forests. Forest Ecol Manag 147:217-243. https://doi.org/10.1016/S03781127(00)00465-5

Koh C-N, Lee P-F, Lin R-S (2006) Bird species richness patterns of northern Taiwan: primary productivity, human population density, and habitat heterogeneity. Divers Distrib 12:546-554. https://doi.org/10.1111/j.1366-9516. 2006.00238.x

Koskimies P (1989) Birds as a tool in environmental monitoring. Ann Zool Fennici 23:153-166 
Liang J, Crowther TW, Picard N, Wiser S, Zhou M, Alberti G, Schulze ED, McGuire AD, Bozzato F, Pretzsch $H$, de-Miquel S, Paquette A, Hérault B, SchererLorenzen M, Barrett CB, Glick HB, Hengeveld GM, Nabuurs GJ, Pfautsch S, Viana H, Vibrans AC, Ammer C, Schall P, Verbyla D, Tchebakova N, Fischer M, Watson JV, Chen HY, Lei X, Schelhaas MJ, Lu H, Gianelle D, Parfenova El, Salas C, Lee E, Lee B, Kim HS, Bruelheide H, Coomes DA, Piotto D, Sunderland T, Schmid B, Gourlet-Fleury S, Sonké B, Tavani R, Zhu J, Brandl S, Vayreda J, Kitahara F, Searle EB, Neldner VJ, Ngugi MR, Baraloto C, Frizzera L, Bałazy R, Oleksyn J, Zawiła-Niedźwiecki T, Bouriaud O, Bussotti F, Finér L, Jaroszewicz B, Jucker T, Valladares F, Jagodzinski AM, Peri PL, Gonmadje C, Marthy W, O'Brien T, Martin EH, Marshall AR, Rovero F, Bitariho R, Niklaus PA, AlvarezLoayza P, Chamuya N, Valencia R, Mortier F, Wortel V, Engone-Obiang NL, Ferreira LV, Odeke DE, Vasquez RM, Lewis SL, Reich PB (2016) Positive biodiversity-productivity relationship predominant in global forests. Science 354:196-210. https://doi.org/10.1126/science.aaf8957

Lindenmayer DB, Margules CR, Botkin DB (2000) Indicators of biodiversity for ecologically sustainable forest management. Conserv Biol 14:941-950. https://doi.org/10.1046/j.1523-1739.2000.98533.x

Lugo AE (1997) The apparent paradox of reestablishing species richness on degraded lands with tree monocultures. Forest Ecol Manag 99:9-19. https:// doi.org/10.1016/S0378-1127(97)00191-6

Lynch JF, Whigham DF (1984) Effects of forest fragmentation on breeding bird communities in Maryland, USA. Biol Conserv 28:287-324. https://doi.org/10. 1016/0006-3207(84)90039-9

Mace GM, Norris K, Fitter AH (2012) Biodiversity and ecosystem services: a multilayered relationship. Trends Ecol Evol 27:19-26. https://doi.org/10.1016/j.tree.2011.08.006

Marsden SJ (1998) Changes in bird abundance follwoing selective logging on Seram, Indonesia. Conserv Biol 12:605-611

Mikusinski G, Gromadzki M, Chylarecki P (2001) Woodpeckers as indicators of bird. Conserv Biol 15:208-217

Miller DL (2016) Distance: distance sampling detection function and abundance estimation. https://rdrr.io/cran/Distance/. Accessed 20 Oct 2018

Moning C, Müller J (2009) Critical forest age thresholds for the diversity of lichens, molluscs and birds in beech (Fagus sylvatica L.) dominated forests. Ecol Indic 9:922-932. https://doi.org/10.1016/j.ecolind.2008.11.002

Moreno-Gutiérrez C, Battipaglia G, Cherubini P, Huertas AD, Querejeta II (2015) Pine afforestation decreases the long-term performance of understorey shrubs in a semi-arid Mediterranean ecosystem: a stable isotope approach. Funct Ecol 29: 15-25. https://doi.org/10.1111/1365-2435.12311

Nasi R, Wunder S, Campos AJJ (2002) Forest ecosystem services: can they pay our way out of deforestation? CIFOR for the global environmental facility (GEF), Bogor, Indonesia

Ne'eman G, Izhaki I (1999) The effect of stand age and microhabitat on soil seed banks in Mediterranean Aleppo pine forests after fire. Plant Ecol 144:115-125. https://doi.org/10.1023/A:1009806507403

Nilsson M-C, Wardle DA (2005) Understory vegetation as a forest ecosystem driver: evidence from the northern Swedish boreal forest. Front Ecol Environ 3:421-428. https://doi.org/10.1890/1540-9295(2005)003[0421:UVAAFE]2.0.CO;2

Oberhauser U (1997) Secondary forest regeneration beneath pine (Pinus kesiya) plantations in the northern Thai highlands: a chronosequence study. Forest Ecol Manag 99:171-183. https://doi.org/10.1016/S0378-1127(97)00203-X

Oksanen J, Blanchet FG, Friendly M, Kindt R, Legendre P, McGlinn D, Minchin PR, O'Hara RB, Simpson GL, Solymos P, Henry M, Stevens $H$, Szoecs E, Wagner H (2016) vegan: Community Ecology Package. https://cran.r-project.org/web/packages/vegan/index.html. Accessed 26 Aug 2018

Osem Y, Brand D, Tauber I, Perevolotsky A, Zoref C (2014) Forest management policy of Israel (In Hebrew), 1st edn. Keren Kayemeth leisrael - Jewish National Fund, Israel

Padoa-Schioppa E, Baietto M, Massa R, Bottoni L (2006) Bird communities as bioindicators: the focal species concept in agricultural landscapes. Ecol Indic 6:83-93. https://doi.org/10.1016/.jecolind.2005.08.006

Paillet Y, Berges L, Hjalten J, Odor P, Avon C, Bernhardt-Römermann M, Bijlsma RJ, De Bruyn L, Fuhr M, Grandin U, Kanka R, Lundin L, Luque S, Magura T, Matesanz S, Mészáros I, Sebastià MT, Schmidt W, Standovár T, Tóthmérész B, Uotila A, Valladares F, Vellak K, Virtanen R (2010) Biodiversity differences between managed and unmanaged forests: meta-analysis of species richness in Europe. Conserv Biol 24:101-112. https://doi.org/10.1111/j.1523-1739.2009.01399.x

Patterson IJ, Ollason JG, Doyle P (1995) Bird populations in upland spruce plantations in northern Britain. Forest Ecol Manag 79:107-131. https:// doi.org/10.1016/0378-1127(95)03619-9
Perevolotsky A, Haimov Y (1992) The effect of thinning and goat browsing on the structure and development of Mediterranean woodland in Israel. Forest Ecol Manag 49:61-74. https://doi.org/10.1016/0378$1127(92) 90160-B$

Quine CP, Fuller RJ, Smith KW, Grice PV (2007) Stand management: a threat or opportunity for birds in British woodland? Ibis (Lond 1859) 149:161-174. https://doi.org/10.1111/j.1474-919X.2007.00742.x

R Core Team (2016) R: A language and environment for statistical computing. $R$ Foundation for Statistical Computing, Vienna https://www.R-project.org/. Accessed 20 Oct 2018

Rankevich D, Warburg M (1983) Diversity of bird species in Mesic and xeric habitats within the Mediterranean region of northern Israel. J Arid Environ 6:161-171

Rey-Benayas JM, Galván I, Carrascal LM (2010) Differential effects of vegetation restoration in Mediterranean abandoned cropland by secondary succession and pine plantations on bird assemblages. Forest Ecol Manag 260:87-95. https://doi.org/10.1016/j.foreco.2010.04.004

Reynaud P, Thioulouse J (2000) Identification of birds as biological markers along a neotropical urban-rural gradient (Cayenne, French Guiana), using co-inertia analysis. J Environ Manag 59:121-140. https://doi.org/10.1006/jema.2000.0338

Reynolds RT, Scott JM, Nussbaum RA (1980) A variable circular-plot method for estimating bird numbers. Condor 82:309-313. https://doi.org/10.2307/1367399

Robbins CS, (1980) Effect of forest fragmentation on breeding bird populations in the Piedmont of the mid-Atlantic region. Proceedings of the 1979 midAtlantic natural history symposium: bird populations-a litmus test of the environment, Washington D.C, pp 31-36

Rosenvald R, Lõhmus A, Kraut A, Remm L (2011) Bird communities in hemiboreal old-growth forests: the roles of food supply, stand structure, and site type. Forest Ecol Manag 262:1541-1550. https://doi.org/10.1016/j.foreco.2011.07.002

Ross BD, Morrison ML, Hoffman W, Fredericksen TS, Sawicki RJ, Ross E, Lester MB, Beyea J, Johnson BN (2001) Bird relationships to habitat characteristics created by timber harvesting in Pennsylvania. J Pa Aca Sci 74:71-84

Schall P, Schulze E-D, Fischer M, Ayasse M, Ammer C (2018) Relations between forest management, stand structure and productivity across different types of central European forests. Basic Appl Ecol 32:39-52. https://doi.org/10.1016/ j.baae.2018.02.007

Schieck J (1997) Biased detection of bird vocalizations affects comparisons of bird abundance among forested habitats. Condor 99:179-190

Schiller G, Ne'eman G, Korol L (1997) Post-fire vegetation dynamics in a native Pinus halepensis mill. Forest on Mt. Carmel. Isr J Plant Sci 45:297-308. https:// doi.org/10.1080/07929978.1997.10676693

Schulze ED, Craven D, Durso A, Reif J, Guderle M, Kroiher F, Hennig P, Weiserbs A Schall P, Ammer C, Eisenhauer N (2019) Positive association between forest management, environmental change, and forest bird abundance. Forest Ecosyst. https://doi.org/10.1186/s40663-019-0160-8

Shochat E, Abramsky Z, Pinshow B (2001) Breeding bird species diversity in the Negev: effects of scrub fragmentation by planted forests. J Appl Ecol 38:1135-1147

Shriner S (2001) Distribution of breeding birds in Great Smoky Mountains National Park. North Carolina State University, Raleigh

Sorek M, Pervolotsky A (2016) State of nature report. https://www.bto.org/ research-data-services/publications/state-nature/2016/state-nature-report2016. Accessed 20 Oct 2018

SPSS (2015) IBM SPSS Statistics. http://www-01.ibm.com/software/analytics/spss/ products/spss-statistics. Accessed 27 Oct 2018

Storch F, Dormann CF, Bauhus J (2018) Quantifying forest structural diversity based on large-scale inventory data: a new approach tosupport biodiversity monitoring. Forest Ecosyst. https://doi.org/10.1186/s40663-018-0151-1

Sweeney O, Wilson M, Irwin S (2011) Woodlands and plantation for breeding birds of native nests in Ireland. Irish Birds 9:181-196. https://doi.org/10.1080/ 00063651003801713

Sweeney OFM, Wilson MW, Irwin S, Kelly TC, O'Halloran J (2010) Breeding bird communities of second-rotation plantations at different stages of the forest cycle. Bird Study 57:301-314. https://doi.org/10.1080/00063651003801713

Tellería JL, Perez-Tris J (2004) Consequences of the settlement of migrant European robins Erithacus rubecula in wintering habitats occupied by conspecific residents. Ibis (Lond 1859) 146:258-268

Urban D, Smith T (1989) Microhabitat pattern and the structure of forest bird communities. Am Nat 133:811-829

Vogeler JC, Hudak AT, Vierling LA, Evans J, Green P, Vierling KT (2014) Terrain and vegetation structural influences on local avian species richness in two mixedconifer forests. Remote Sens Environ 147:13-22. https://doi.org/10.1016/J.RSE. 2014.02.006 
Von Dem BJ, Spaar R, Schmid H, Schröder B (2008) Modelling the recent and potential future spatial distribution of the ring ouzel ( Turdus torquatus ) and blackbird ( T. merula ) in Switzerland. J Ornithol 149:529-544. https://doi.org/ 10.1007/s10336-008-0295-9

Whelan CJ, Maina GG (2005) Effects of season, understorey vegetation density, habitat edge and tree diameter on patch-use by bark-foraging birds. Funct Ecol 19:529-536. https://doi.org/10.1111/j.1365-2435.2005.00996.x

Wilcove DS (1989) Protecting biodiversity in multiple-use lands: lessons from the US forest service. Trends Ecol Evol 4:385-388. https://doi.org/10.1016/01695347(89)90108-0

\section{Submit your manuscript to a SpringerOpen ${ }^{\circ}$ journal and benefit from:}

- Convenient online submission

- Rigorous peer review

- Open access: articles freely available online

High visibility within the field

- Retaining the copyright to your article

Submit your next manuscript at $\boldsymbol{\nabla}$ springeropen.com 